\title{
Computing maximum flow rates
}

\author{
Françoise A. Valentini, $M D, P h D$ \\ Médecine Physique et de Réadaptation Hôpital Rothschild, Paris, France
}

Cite as: Can Urol Assoc J 2014;8(3-4):e215. http://dx.doi.org/10.5489/cuaj.1765

Published online March 11, 2014.

I found $C U A J$ 's article by Richard and colleagues very interesting. ${ }^{1}$ I agree with the authors' conclusion that a free uroflow (FF) should be performed before any urodynamic study. However, the conclusion that the presence of a $6-\mathrm{Fr}$ catheter is obstructive and results in a significant decrease of $\mathrm{Q}_{\max }$ (about $8 \mathrm{~mL} / \mathrm{s}$ ) is not what we have experienced.

With my colleagues, we have obtained very different conclusions in women. ${ }^{2,3}$

Firstly, the large decrease in $\mathrm{Q}_{\max }$ observed during intubated flow (IF) when compared with FF during the same session is only observed for $38 \%$ of our studied population. Mathematical modelling for initial bladder volume is $400 \mathrm{~mL}$ (normal detrusor, normal urethra) and gives a maximum decrease of $\mathrm{Q}_{\max }$ as $3.4 \mathrm{~mL} / \mathrm{sec}$ (catheter $7 \mathrm{Fr}$ ). Theoretical analysis demonstrates that differences between subgroups with and without decrease of $\mathrm{Q}_{\max }$ can only be due to a urethral compression.

Secondly, recent theoretical computations using the VBN mathematical micturition model have given the following results (comparison for different volumes, catheter size, urethral obstruction, detrusor force). Looking only at the effect of bladder volume, with or without catheter 6Fr (normal detrusor, normal urethra): From 200 to $400 \mathrm{~mL}$ without catheter $\Delta \mathrm{Q}_{\max }=+8.3 \mathrm{~mL} / \mathrm{sec}$, while the maximum catheter effect is $-2.25 \mathrm{~mL} / \mathrm{sec}$. So, the volume effect is always higher than the catheter effect.

Competing interests: Dr. Valentini declares no competing financial or personal interests.

\section{References}

1. Richard P, Icaza Ordonez N, Tu LM. The effect of a 6Fr catheter in women: Are they obstructive or not? Can Urol Assoc J 2013;7:185-8. http://dx.doi.org/10.5489/cuaj.1320

2. Valentini FA, Robain $G$, Hennebelle DS, et al. Decreased maximum flow rate during intubated flow is not only due to the urethral catheter in situ. Int Urogynecol J 2013;24:461-7. http://dx.doi.org/10.1007/s00192-012-1856-2
3. Valentini FA, Nelson PP, Zimmern PE. Obstructive effect of a urethral catheter during voiding: Myth or realty? Urotoday Int J 2013;6:art 61. http://dx.doi.org/10.3834/uij.1944-5784.2013.10.08

Correspondence: Dr. Françoise A. Valentini, ER6-Université Pierre et Marie Curie (Paris 06) ; Médecine Physique et de Réadaptation Hôpital Rothschild, 5 rue Santerre 75012 Paris, France; francoise.valentini@rth.aphp.fr

\section{How appropriate is circumcision?}

\section{Dennis Harrison}

Cite as: Can Urol Assoc J 2014;8(3-4):e215 http://dx.doi.org/10.5489/cuaj.1766

Published online March 11, 2014.

The estimate of the newborn circumcision rate in Canada does not agree with the reference provided. ${ }^{1}$ The authors state that the rate is "about 50\%," whereas their reference (Sauve, Royle, Chalmers et al) report a rate of $31.9 \% .^{2}$ Sauve and colleagues also note that rates across provinces and territories range from $6.8 \%$ to $44.3 \%$.

Such wide variations in surgical rates raise questions about appropriateness of treatment.

Competing interests: Dr. Harrison declares no competing financial or personal interests.

\section{References}

1. DeMaria J, Abdulla A, Pemberton J, et al. Are physicians performing neonatal circumcisions well-trained? Can Urol Assoc J 2013;7:260-4. http://dx.doi.org/10.5489/cuaj.200

2. Sauve R, Royle C, Chalmers B, et al. How many male infants get circumcised in Canada-and why? CPS Abstracts 2008. http://www.pulsus.com/cps2008/abs/070.htm. Accessed March 4, 2014.

Correspondence: Dennis Harrison, Independent Researcher, Vancouver, BC; harrisond@telus.net 